\title{
THE EFFECT OF GUIDED INQUIRY LEARNING MODEL ASSISTED BY VIRTUAL LABORATORY TO STUDENT'S LEARNING ACHIEVEMENT IN TEMPERATURE AND HEAT TOPIC IN CLASS X OF SMA N 1 LANGSA ACADEMIC YEAR 2014/2015
}

\author{
Mawarni Saputri and Motlan \\ Jurusan Fisika FMIPA Universitas Negeri Medan \\ Jalan Willem Iskandar Pasar V Medan, Sumatera Utara \\ Putrimawar.pm@gmail.com
}

\begin{abstract}
The aim of this research was to know the effect of guided inquiry learning model assisted by virtual laboratory to student's learning achievement in temperature and heat topic in class X of SMA N 1 Langsa Academic year 2014/2015. The research method was quasi experimental. The population were all students of class X SMA N 1 Langsa Academic Year 2014/2015 that consist of 11 classes. Two classes selected by cluster random sampling as sample. One class as experiment class using guided inquiry learning model assisted by virtual laboratory and another class as control class using conventional learning. The instrument in this research were multiple choices and observational sheet. Multiple choices with 5 options and 20 questions were valid while observational sheet is used to measure the student's activity during learning process. The results that were obtained: post test mean value of the experiment class was 78.70 and 63.54 was the mean value of the control class. Normality and homogeneity of the test result from the both samples was normal and homogenous. From the calculation of $t$ test for post test data, obtained that $t_{\text {count }}$ value was bigger than $t_{\text {table }}$ value. Based on the observation that has been done by observers with using observational sheet obtained that student's activity in experiment class is greater than control class. So, it can be concluded that there was the significant effect of guided inquiry learning model assisted by virtual laboratory to student's learning achievement in temperature and heat topic in class X of SMA N 1 Langsa Academic year 2014/2015.
\end{abstract}

Keywords: Guided inquiry learning model, virtual laboratory, student's learning achievement, student's activity.

\section{INTRODUCTION}

National development covers a wide range of fields, one of them is education. Education is one of the important factors in advancing and educating the nation. Through education, nation can develop a variety of sectors which needed for the continuity of the nation's technology, economy, industry, and so forth. Education prepares qualified human resources in order to run their lives well and to be able to face the increasing of fierce global competition. Every nation that has a good quality of education will be able 
to face global competition because education is a process of producing the next generation. However, if the output of the educational process is unsuccessful then a nation will be difficult to achieve progress. For the people who want to get ahead, education must be seen as a need as well as other needs such as food, clothing, and shelter. However, it seems very sad to see the condition of education in Indonesia today. Many problems arise, ranging from inadequate facilities, curriculum changing, unprofessional educators, to the personality of students that is far from the expectation.

One of the problems facing our education is the problem of lack of learning process. In the learning process, children are less encouraged to develop the ability to think. The learning process in the classroom directed to the child's ability to memorize information. Brain students are forced to remember and hoard a variety of information without being required to understand the information he remembered it to connect with everyday life. As a result, when students graduate from school, they are theoretically clever but they are bad in application (Sanjaya, 2006).

Based on the research conducted by the Programme for International Student Assessment (PISA) on the literacy skills of reading, math and science students ages 15 years in the junior / MTS / SMA / MA / SMK in 2013, Indonesia was the rank 64 th of 65 countries (Kemendikbud, 2013).

In addition, the low ability of Indonesian students are also reflected in the failure of the national exam (UN). Graduation rate in 2014 decreased compared to the previous year. From the 9.970 students who do not pass the exam, specifically for high school (SMA) / (MA) totaling 7.811 students did not pass, and most fall in the Aceh province. (Koto, 2014). Based on research interviews with one of the teacher of physics class X SMA Negeri 1 Langsa known that the minimum completeness criteria (KKM) for subjects of physics is 75 . The value of the data is known semester final exams are still many students who have not been thoroughly studied, namely around $60 \%$ and from the results of observations conducted by researcher, learning model that is often implemented by teachers is the conventional model with a lecture method. And in the learning process also seldom use a learning media. It makes the teacher dominates the teaching and learning activities in the classroom students become passive. Therefore, there should be a shift of learning process paradigm. Change of paradigm in question is a change of learning that are teacher-centered to student-centered. It also calls for an innovative learning model to overcome the problems of education, especially science.

One of the efforts in learning physics is to use the model of guided inquiry. Kuhlthau (in Sofiani, 2011) states that one of the learning model that involves the activity of students to find the concept itself is the model of guided inquiry. Guided inquiry model is a way in the inquiry-based learning used in science education. Guided inquiry learning model emphasizes the process of knowledge discovery independently where students as a learning center. The role of the teacher is only a facilitator who guides the students in the process of knowledge discovery. This 
is be in accordance with the statement Bilgin, (2009) and Ozdilek, (2009) that the guided inquiry learning model, teachers and students play an important role in the process of asking, answering, and compile knowledge, where the teacher directing how students acquire knowledge and students trying to gain knowledge with guidance teacher.

Learning can be more effective, efficient and attractive if it's facilitated by interactive learning media. The use of instructional technology is a positive impact on the interest and enthusiasm of learners in the learning process. One form of technology that have conformity with guided inquiry theory is a virtual laboratory. Utilization of a virtual laboratory in the learning process makes the learning process more effective in terms of time and improve student achievement (Tatli \& Ayas, 2013).

Research of Bajpai, (2013) entitled "Developing Concepts in Physics Through the Virtual Lab Experiment: An Effectiveness Study" concluded that the concept of learning through a virtual laboratory of the photoelectric effect is more effective than the real lab. The study also shows the use of a virtual laboratory in physics learning better in improving students' understanding of concepts rather than learning through real lab. Wijaya, (2013) examined the influence of inquiry learning model assisted by virtual laboratory for understanding physics concepts to eighth grade students of SMP Negeri 1 Negara was obtained result that physics learning is very effective in improving the understanding of physics concepts than models of inquiry learning and conventional learning model.

Based on the problems above, the author wishes to know the effect of guided inquiry learning model assisted by virtual laboratory in teaching and learning process, then the author feels need to carry out a study entitled: "The Effect of Guided Inquiry Learning Model Assisted by Virtual Laboratory to Student's Learning Achievement in Temperature and Heat Topic in Class $\mathrm{X}$ of SMA N 1 Langsa Academic Year 2014/2015".

\section{RESEARCH METHOD}

The research was conducted in SMA N 1 Langsa that were active in the Academic Year 2014/2015. The population of this research were all students in class $\mathrm{X}$ at SMA N 1 Langsa Academic year 2014/2015, while the sample was selected by cluster random sampling which are divided into two classes consisting of control class and experiment class. The type of this research is a Quasi Experimental with pretest-posttest control group design.

The research design can be shown in table 1:

Table 1. Research design

\begin{tabular}{|c|c|c|c|}
\hline Group & $\begin{array}{c}\text { Pre } \\
\text { Test }\end{array}$ & Treatment & $\begin{array}{c}\text { Post } \\
\text { Test }\end{array}$ \\
\hline $\mathrm{E}$ & $\mathrm{T}_{1}$ & $\mathrm{X}$ & $\mathrm{T}_{2}$ \\
\hline $\mathrm{C}$ & $\mathrm{T}_{1}$ & $\mathrm{Y}$ & $\mathrm{T}_{2}$ \\
\hline
\end{tabular}

Description:

$\mathrm{E}=$ Experiment class

$\mathrm{C}=$ Control class

$\mathrm{T}_{1} \quad=$ Pre-test for experiment class and control class

$\mathrm{T}_{2} \quad=$ Post-test for experiment class and control class

$\mathrm{X}=$ Treatment with Guided 


\author{
Inquiry Learning Model \\ Assisted by Virtual \\ Laboratory \\ $\mathrm{Y} \quad=$ Treatment with \\ conventional learning
}

The instrument in this research were multiple choices and observational sheet. Multiple choices with 5 options and 20 questions were valid while observational sheet is used to measure the student's activity during learning process.

\section{RESULT AND DISCUSSION Research Result}

Before the material is taught, students were given a pre test to determine students' initial ability of the material studied in the experimental class and control class. The average of student pre test value in experiment class was 33.04 while average of student pre test value in control class was 33.13. To know clearly the comparison of pre test value in experiment class and control class can be seen in chart below:

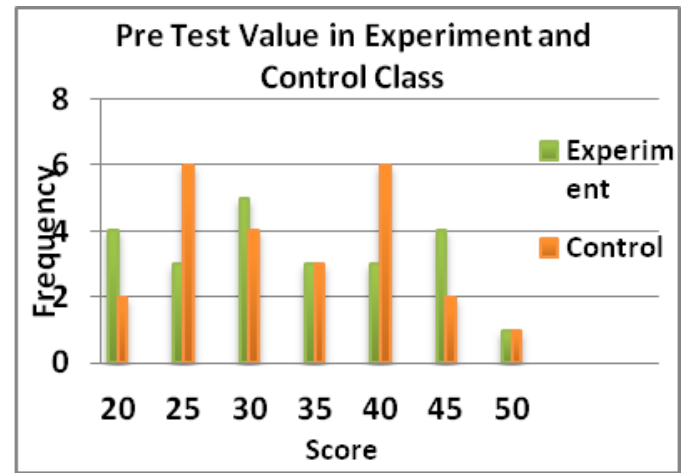

Figure 1. Chart of pre test value in experiment and control class

After given treatment in experiment class with Guided inquiry learning model assisted by virtual laboratory has average value 78.70 with standard deviation was 9.07 while in control class after given treatment with conventional learning has average value 63.54 with standard deviation was 11.84. The comparison of post test value in both of classes can be seen in chart below:

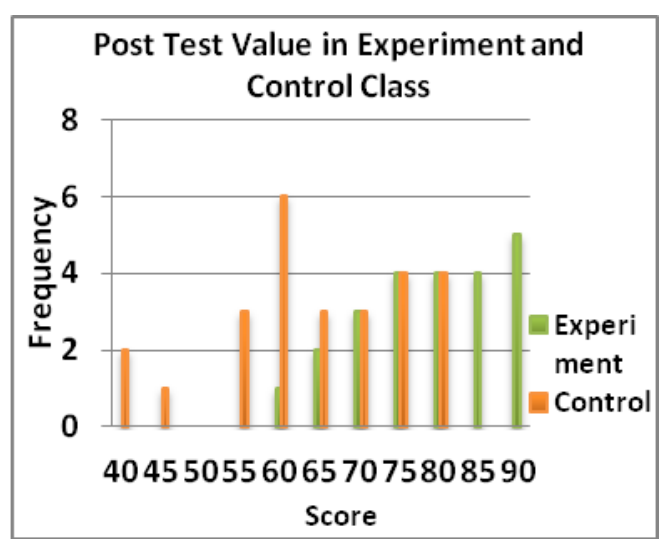

Figure 2. Chart of post test value in experiment and control class

Before doing the test of hypothesis, the first thing to be done is normality test with Liliefors test. It obtained that the pre test value in two samples have normal data or $\mathrm{L}_{\text {count }}<\mathrm{L}_{\text {table }}$ in significant level 0.05.

Based on the calculation of normality test, the data in the experimental class and control class for the value of pre test and post test showed that the distribution of the pre test and post test in both classes are normally distributed.

Normality test showed that the sample comes from a normal distribution, then the next step is homogeneity test. Testing homogeneity of the data to determine whether the samples used in the study come from the homogeneous population or not. Homogeneity test calculated with $\mathrm{F}$ test with $a=0.10$ and testing criteria that must be filled is $\mathrm{F}_{\text {count }}<\mathrm{F}_{\text {table. }}$.

Based on the result of the homogeneity test calculation on the data pretest showed that both samples come from a homogeneous variance and for post test data was 
obtained that post test in both samples also come from a homogeneous variance.

After the data was normal distribution and homogeneous then the next step to be done is hypothesis test. Hypothesis data testing was done using $t$ test two tails and test one tail. $\mathrm{T}$ test two tails is used to determine the similarity of students ability at the first both of samples. From the calculation of $t$ test two tails obtained that initial student ability in experiment and control class were same. While $t$ test one tail is used to know the different of student ability after given a treatment. From the calculation of $t$ test one tail obtained that $t_{\text {count }}>t_{\text {table }}$ that is $4.78>1.68$ then $\mathrm{H}_{0}$ is rejected and $\mathrm{Ha}$ is accepted. It means that there was effect of Guided inquiry learning model assisted by virtual laboratory to student's learning achievement on temperature and heat topic in class $\mathrm{X}$ of SMA N 1 Langsa Academic Year $2014 / 2015$.

\section{Observation}

This observation aims to observe student's activity during learning process by using guided inquiry learning model assisted by virtual laboratory and conventional learning. The comparison between result of student activity in experiment and control class, showed in figure below:

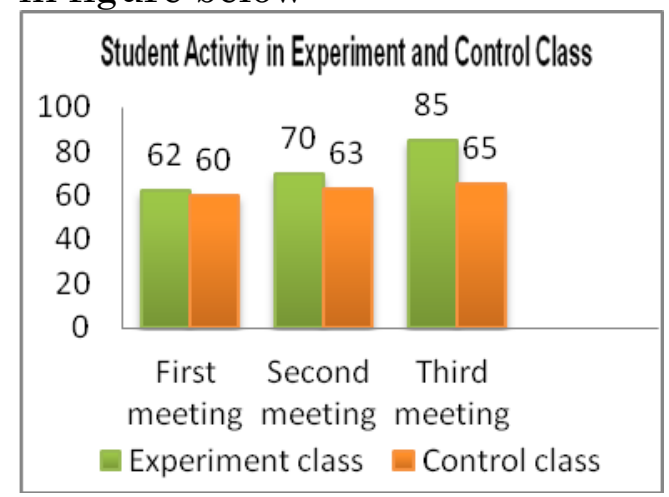

Figure 3. Chart of student's activity in experiment and control class

The relationship between pre test, activities and student's post test value in experiment class can be seen in the chart below:

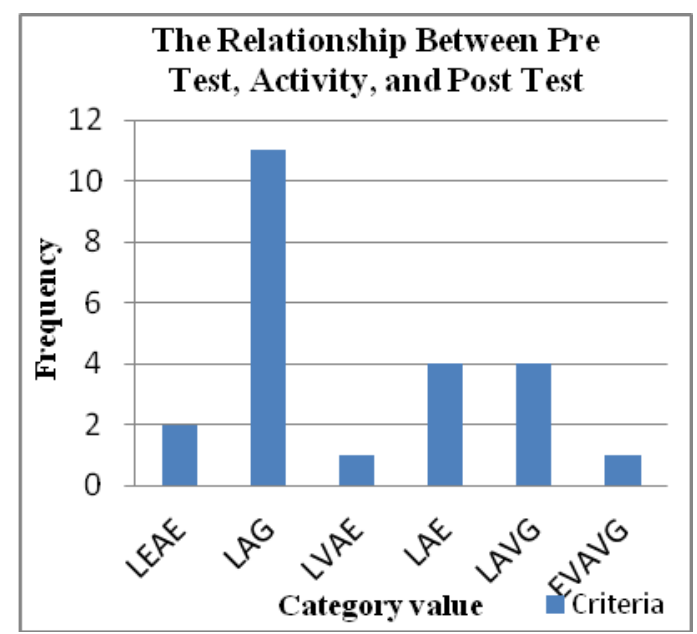

Figure 4. Chart of category pre test value, activity and post test

Explanation:

LEAE

: Less, Enough, Active, Enough

LAG : Less, Active, Good

LVAE : Less, Very Active, Enough

LAE : Less, Active, Enough

LAVG : Less, Active, Very Good

EVAVG : Enough, Very Active, Very Good

Students who have Less criteria, Enough Active, Enough (LEAE) are 2 people (8.69\%), students who have Less criteria, Active, Good (LAG) are 11 people (47.83\%), student who has Less criteria, Very Active, Enough (LVAE) is 1 person (4.35\%), students who have Less criteria, Active, Enough (LAE) are 4 people (17.39\%), students who have Less criteria, Active, Very Good (LAVG) are 4 people (17.39), and student who 
has Enough criteria, Very Active, Very Good is 1 person (4.35\%).

\section{Discussion}

The results showed that there was effect by using Guided Inquiry Learning Model assisted by virtual laboratory to student's learning achievement in Temperature and Heat topic in class $\mathrm{X}$ of SMA $\mathrm{N} 1$ Langsa. This is reinforced by the acquisition value of the student's average pre test in the experimental class was 33.04 and the average post test value was 78.70 while the values obtained in the control class of student's average pre test value was 33.13 and average post test value was 63.54. In experiment class, the learning is student centered. The syntax of guided inquiry learning model are orientation, exploration, concept formation, application, and closure. It makes the students became more active in the class. In the control class, learning is teacher centered so it makes student became passive and make the learning achievement in experiment class using guided inquiry leaning model higher than learning achievement in control class by using conventional learning.

Guided inquiry learning model does not only increase student learning achievement, but also can enhance student learning activity especially skill. Based on the data obtained, it can be concluded that guided inquiry model can be applied to the students individually and also groups. Guided inquiry assisted by virtual laboratory has several advantages over real learning lab and conventional learning model. Virtual laboratory tend to be more flexible in its use. Moreover, students are more enthusiastic in learning involving technology in it, such as the use of simulation and other technologybased learning media.

Guided inquiry learning model has been researched by Wijaya (2013), he concluded that the implementation of inquiry learning model assisted by virtual laboratory in physics learning is very effective in improving the understanding of physics concepts than models of inquiry learning and conventional learning model. And by Bilgin (2009), the results showed that students in the experimental group had better understanding of acid and bases concepts and more positive attitude toward guided inquiry instruction. And also by Putri (2014), she said research result showed applied of guided inquiry learning model give significant effect to student learning outcomes. While learning assisted by virtual laboratory has been researched by Tatli \& Ayas (2013), they said that utilization of a virtual laboratory in the learning process makes the learning process more effective in terms of time and improve student achievement. And by Bajpai (2013), he concluded that the concept of learning through a virtual laboratory of the photoelectric effect is more effective than the real lab. The study also shows the use of a virtual laboratory in physics learning better in improving students' understanding of concepts rather than learning through real lab.

The result of this research was suitable with their research result, where in their result gotten student's learning achievement taught by Guided inquiry learning model assisted by virtual laboratory is better than conventional learning.

Although the guided inquiry learning model has made a better learning achievement compared to 
conventional learning, but there are some things constraints in doing research, namely 1) Researchers have not been up to manage time so that all the syntax is less effective during the implementation of learning process 2) Students still unfamiliar with this learning model because this model has not been applied to the school.

\section{CONCLUSION AND SUGGESTION Conclusion}

Based on research result, data analysis, and discussion can be concluded that the learning achievement in experiment class using Guided inquiry learning model assisted by virtual laboratory is greater than learning achievement in control class using conventional learning. Student's activity as long as using guided inquiry learning model increase became good category. The result of hypothesis test shows $t_{\text {count }}>$ $t_{\text {table }}$ that is $4.78>1.68$. It means there was the effect of Guided Inquiry Learning Model Assisted by Virtual Laboratory to student's learning achievement in temperature and heat topic in class X of SMA N 1 Langsa Academic Year 2014/2015.

\section{Suggestion}

For the next researcher in order to make a better of instructional media which use to teach the topics, to support Guided inquiry learning model in Temperature and Heat topic. For the next researcher in order to give more attention and guidance to students who are less active. For the next researcher who wants research about Guided inquiry learning model assisted by virtual laboratory to use the time as effectively as possible.

\section{REFERENCES}

Bajpai, M., (2013), Developing conceps in physics through virtual lab experiment: An effectiveness study. $A n$ International Journal of Education Technology, 3(1): 4350.

Bilgin, I., (2009), The effects of guided inquiry instruction incorporating a cooperative learning approach on university students ${ }^{\text {ee }}$ achievement of acid and bases concepts and attitude. Scientific Research and Essay, 4 (10): 1038-1046.

Kemendikbud, (2013), Survei internasional PISA, http://litbang.kemdikbud.go. id/index.php/surveiinternasional-pisa, (accessed on January $15^{\text {th }}, 2015$ ).

Koto, H., (2014), 780 Siswa SMA/MA di Aceh tak lulus UN, Waspada Online, http://waspada.co.id/index.php? option $=$ com_content\&view $=$ arti cle\&id=325195:780-siswa-sma-di-aceh-tak-lulusun\&catid=13; acehitemid $=26$, (accessed on January 19th, 2015).

Özdilek, Z., and Bulunuz, N., (2009), The Effect of a Guided Inquiry Method on Pre-service Teachers Science Teaching Self-Efficacy Beliefs. Journal of Turkish Science Education, 6 (2): 24-42.

Putri, R,W., (2014), The Effect of Guided Inquiry Learning Model on Students Learning Outcomes in Topic Temperature and Heat in Class X SMA N 1 Berastagi Academic Year 2014/2015, Skripsi, FMIPA, UNIMED 
Sanjaya, W. (2006), Strategi Pembelajaran, Kencana, Jakarta.

Sofiani, E, (2011), Pengaruh model inkuiri terbimbing terhadap hasil belajar fisika siswa pada konsep listrik dinamis, Skripsi, FMIPA, UIN Syarif Hidayatullah, Jakarta.

Tatli, Z., and Ayas, A., (2013), Effect of virtual chemistry laboratory on students' achievement. Journal of Educational Technology and Society, 16(1): 159-170.

Wijaya, I G., (2013), Pengaruh model pembelajaran inkuiri berbantuan virtual laboratory terhadap pemahaman konsep fisika siswa kelas viii smp negeri 1 negara tahun ajaran 2012/2013, Skripsi, Universitas Pendidikan Ganesha, Bali. 